\title{
Egyptian Media Coverage and Cultural Differences Impact In Perceiving the US Presidential Candidates 2016
}

\author{
Fatma El- Zahraa EI Sayed *
}

\begin{abstract}
:
This paper aims to investigate the impact of the cultural differences of the same society in interacting and anticipating the development of foreign affairs that occupied major space of media attention globally and locally. US presidential elections that took place in Nov. 2016 was one of the salient foreign affairs that occupied the Egyptian media mainstream for several months specially the what so called 'Official Media" represented in this research with AlAhram newspaper. The research assumes significant variance in interacting with US presidential elections between two groups of Egyptians (280 participant) differ in their type of education and cultural backgrounds. The research illustrates the mainstream of the Egyptian media coverage of the elections during the time April- Dec 2016 in 322 articles (230 news-92 opinion) identifying 12 frames of news which are; patriotism, promises, determination, differentiation, situation adjustment, percussive, accusation, attacking, conspiracy, diplomacy, informative, and expectations. Six of these frames have significance relationship with some variables tested by Kruskal-Wallis (0.05).

The results showed no significant differences between the two groups in describing the presidential candidates with certain characteristics or anticipating the next president based on their knowledge about the American society. Some other significant results in both analytical and survey levels are supposed to be beneficial for further researches.
\end{abstract}

\section{Keywords:}

US Presidential Elections, Speech Codes Theory, Egyptian Media, Cultural studies.

*Associate Professor, Department of Journalism, Faculty of Mass Communication - Cairo University 


\section{Introduction:}

Cultural distinctiveness is one of the main factors that produces certain style of self/community structures and strategic actions. The main idea based on G. Philipsen's most interpretive theory; Speech Codes (1992). The theory introduces essentially six propositions to explain the conditions that are important to understand the mechanism of codes production through speeches within either the same culture or between two or more different cultures. (Philipsen, G. 2001, 2005, 2010)

Referring to the first proposition of the theory; "Wherever there is a distinctive culture, there is to be found a distinctive speech code", I suppose that there should be remarkable differentiations between the codes of speech perceived by Egyptians and make them portray both US presidential candidates 2016 with characteristics that are congruent with their cultural experience. The use of words in televised interviews and debates links candidates' personalities with certain characteristics. (Slatcher, R., Chung, K., Pennebaker, J. \& Stone, L. 2007). Moreover, candidates' nonverbal vocalization is considered as a metric of commanding presence in the presidential campaign (Greogory JR, S., \& Gallagher, T. 2002).

The paper concentrates on the descriptions that are given indirectly to both US presidential candidates Hillary Clinton and Donald J. Trump by one of the major national Egyptian newspapers (Al-Ahram) during their election campaigns and after Trump's winning in Nov 2016. The traditional media in Egypt continue to play a major role in amplifying political brand aspects of the presidential candidates along with social media intelligence (Oates, S., Moe, w. 2016).

The analysis combines the news and opinion content by identifying the news frames that represent each candidate along with extracting the central idea embedded in the opinion articles. On the other hand, the paper compares the characteristics inferred from media with each candidate's characteristics perceived directly by people who are more interested in following the electoral campaigns through various types of media platforms. 


\section{Literature Review:}

There is a large volume of studies investigating the correlations between presidential candidates, personal characteristics and several dependent variables including their general image, voters' perceptions and the role of the media in constructing these perceptions, candidate appearance and the potential impact on the elections outcomes, the charisma and other personal qualities in its relation with the preferences of the well or less educated publics, and the perceived positive and negative points in the psychological profile.

"Homophile" is the only image facet that consistently predicted voter intentions, while some positive traits such as "intelligence" and "charming" seem to work against candidate. (Warner, B.R\& Banward, M.C. 2016). In the relation between the presidential candidates' personalities and the media coverage, there is some evidence that journalists tend to write more stories about appealing personalities for at least sixty years in the US and more robust presidents got more general and personal media coverage. (Streitmatter, R. 1985) In contrast, news coverage of Los Angeles Times Poll increased the salience of the trait "stubborn" in assessing president George Bush in 2004. Similarly, the unrestrained discourse and lack of traditional presidential qualities in Trump case were reasons of his projection as unique persona for his supporters and make expectations of operating politics in an unusual way. (Dow, B. 2017)

In a comparison between the significance of the candidate's attributes in the presidential elections in the present and in the past, it seems that characteristics such as, competence, integrity, reliability, charisma, and personnel that were important in the era of Johnson, Nixon, and Regan, become less relevant to the outcome of presidential elections in recent years. (Wattenberg, M. 2016)

"The Clinton Factor" has been diagnosed in 2000 presidential elections as a determining factor of his personal image. The main predictors involved his job performance, images, political party identification, ideology, and electability. The findings indicated significant effects of "the Clinton factor" on the primary and generalelection voters. In this elections, presidential candidates presented themselves in photographs to emphasize their appeal and reverse the 
negative media portrayals. (Wattier, M. J. 2004, Verser, R. \&Wicks, R. 2006).

From a sociological point of view, Obama rhetoric and actions manifests charisma comparing to Palin in 2008 elections from the lenses of Max Weber theory of social change. The charismatic leadership in this context translates the relationship between the leader, the followers, and the social circumstances that enable the leader to provide solutions for the problems facing the community. (Bowden, G. 2010) Moreover, the candidate's image composition seems to be influenced by dichotomy between candidate issue positions and candidate persona impressions. (Hacker, K. et al, 2000).

Privatization and personalization are main issues in the media debate about presidential candidates in Chile with an increasing tendency to allocate more space to privatization. Both concepts have been addressed to link the personalization concept with individual attributes of candidates which include, competence, integrity, confidence, charisma, and ideology, while the privatization concept refers to private life elements like family, heritage, biography, appearance, and business aspects. (Porath, W., et al. 2014)

In Mexico, the presidential candidate is mainly evaluated for his capability, competence, and leadership. This result derived from a candidate's brand image scale designed to examine whether political candidates are brands. The scale illustrates five factors determine the candidate branding encompasses empathy, openness, agreeableness, competence, and handsomeness. (Hacker, K. et al, 2000) On the other hand, "morality" in terms of decency, integrity, responsibility, and fairness are being concluded as the most common personality trait has been discussed with other three general dimensions of political candidate's characteristics such as sincerity, empathy, and drive. This finding derived from content analysis of the political leaders debates in different countries (Benoit, w. 2013).

The appearance of the candidate tends to influence the election outcomes when associating the party brand level. Some marketing values include party brand, image, advertising spending, have impacted the participants' evaluations that were more accurate when 
assessing races with successful Republican candidates than successful Democratic candidates. (Hoegg, J\& Lewis, M.V. 2011)

Some cross-sectional studies investigate the reasons that make some candidates are perceived more favourable than others, they suggest that competence judgments are essential on actual vote outcomes. It argues that both familiarity and attractiveness breed positivity and the major effect of attractiveness is derived from several characteristics encompass ambitious, trustworthy, and self-disciplined. (Verhulst, B. et al 2010)

A study focused on the potential differences in perceiving presidential candidates between college educated people and less educated concluded that the later are not so poorly as one might have assumed, however, the better educated place more weight on the candidate's personal attributes as they feel this is a subject they can get more accurate information about the candidate. (Glass, D. P. 2001).

From a psychological perspective, a "Big Five" instrument that includes qualities of extroversion, amicability, conscientiousness, emotional stability, and openness, has been utilized to measure brand personality parameters of the 2009 presidential elections candidates in Romania. The findings demonstrate that the slight variation between candidates may entail a severe competition in certain issues, however, the huge distances may involve a secure position for the candidate. (Petre, D. et al 2010)

Through gender lenses, some studies suggest an impact of the candidate gender on the publics image preferences. The male politicians are believed to be more knowledgeable, trustworthy, and convincing whilst female politicians present the same speech verbatim. Moreover, the young males favour male over female politicians in term of communication skills. (Aalberg, T., \&Jenssen, A.T. 2007). The US presidential elections in 2016 gave a clear evidence of scholars' misjudging the power of gender, however it could be evaluated as a referendum on publics tolerance with traditional politics. (Dow, B. 2017)

Furthermore, the female candidate in the Korean elections 2007 used gender stereotypes in the online communication to articulate 
traits of compassion to female-identified issues, and link qualities of competence to traditionally male-identified issues. (Kim, K. 2012)

\section{Methodology:}

Two types of data collecting methods are used to investigate the research questions. The content analysis to analyze news and articles of Al-Ahram newspaper and survey to collect data from 280 Egyptians divided into two groups, 140 are mainly Arabic Educated in governmental universities and 140 are English Educated in private or foreign universities.

The objectives of this study are to answer the following questions:

RQ1- What are the main characteristics introduced by Egyptian media about both US presidential candidates; Hillary Clinton and Donald J. Trump?

RQ2- What are the major central ideas included in the opinion articles of the national newspapers?

RQ3- What are the dominant scopes used to frame news reports of each presidential candidate in different stages of the election campaign?

RQ4- What is the order of media exposure preference of Egyptians to follow the campaigns news?

RQ5- Are there any significant relationships between demographic variables (age- gender-education) and the characteristics and descriptions given to the candidates?

RQ6- Is there any significant difference between Egyptians with foreign education and others with Arabic education in considering one of the candidates more representative to the American values and more convincing to the American citizens than the other?

RQ7- What are the potential characteristics given to each US presidential candidate referring to the education variations of the Egyptians?

Kruskal Wallis, T. Test and Chi-Square tests are used to investigate the significance of differences between groups $(a \leq 0.05)$.

\section{Results:}


The results are divided into three sections. First section is about the content analysis of Al- Ahram newspaper in portraying the main frames that introduce the US presidential elections 2016 in both news and opinion articles. Secondly, the field study survey of two different groups of Egyptians categorized in accordance with variations of education type and other variables including; gender, age, media consumption and general interests. Finally, a comparison between the two previous results is conducted to estimate the potential points of attitudes intersections with the research main topic may exist in national level represented by semi-official media and public level represented by the Egyptian people from different cultural/educational backgrounds.

The total articles published in Al-Ahram about US presidential elections are 322 from April to December 2016. However, we can observe a gradual upward trend starts in June (3.4\%) and reaches its peak in November (38.8\%), then suddenly dropped in December $(0.9 \%)$ which seems normal regarding the development of the elections campaigns.

Most of the content is news $(71.4 \%)$ and the rest is opinion articles $(28.6 \%)$. In addition, majority of the content is about the male candidate $(38.8 \%)$, however $(31.4 \%)$ is about both candidates and only $(29.8 \%)$ is about the female candidate.

Graph.1 (P.20)
-------------------------------
Table.1 (P.20)

1- Al-Ahram introduced the elections campaign content whereby 12 frames to introduce certain candidate or to describe both. The most frequent frame is "Expectations" followed by "Attacking" and the least frequent frames are: "Informative" and "Patriotism". In table 2 we can observe some variations in the frames order between both candidates. The researcher investigates the significance of these frames with Kruskal Wallis test (0.05) and proves using some frames with candidates. 
Table. 2 (P.20)

Table. 3 (P.21)

2- The major central ideas included in the articles are seven: 1) electing Clinton is against US interests. 2) electing Trump is against US interests. 3) Both of candidates are inappropriate for US interests. 4) World future is unclear if Trump become the president. 5) World future is worse if Clinton become the president. 6) Trump is better than Clinton for the US and the world. 7) Clinton is better than Trump for the US and the world.

Table. 4 (P.21)

We can conclude obviously that the thesis with bigger mean is more frequently embedded in the opinion articles which says that both candidates are not illegible for presidency. The differences between categories are proven whereby Chi-Square test. (0.05)

Table. 5 (P.21)

3- Some characteristics were included inside news frames and opinion articles describing each candidate with certain traits. The traits that describe Trump are: racist, cyclonic, insufficient, determined, trustful, corrupted, narcissist, filthy rich and ignorant. However, the traits that describe Clinton are: corrupted, efficient, liar, devilish, traitor, criminal and less harmful. All traits have significance tested whereby Chi-Square and Kruskal Wallis (0.05) with almost same values except: narcissist and filthy rich for Trump and liar, devilish and traitor for Clinton. 
Table. 6 (P.22)

Table. 7 (P.22)

Table. 8 (P.23)

4- 94.6\% of the sample is Egyptian nationality and 5.4\% from other Arab nationalities living in Egypt and study in its universities. Females are $65 \%$ and males are $35 \%$. The biggest age category (16$25)$ is mostly for undergraduate students in the national education funded by the Egyptian government (82.9\%). Majority of the research segments are interested in following the American presidential elections and are intensive viewers of its events (57.9\%) specially the presidential elections, specifically the third one $(30.7 \%)$. However, most of them $(61.8 \%)$ do not remember exactly which debate they've been watching.

5- It appears that there is a general order of consuming media as a medium to follow the proceedings of the presidential campaigns that typically match the normal habits of interacting with media that characterize this category of age. Facebook occupies the first and second ranks, however, YouTube shows up in the third position. Twitter, international newspapers, and broadcasting appear at the bottom of the list. Kruskal Wallis investigates the significance of differences between the two groups in using media to follow the presidential elections and proves it for Facebook, Twitter, international newspapers, Egyptian web sites and Egyptian TV channels.

Table. 9 (P.23)

6- Participants identify certain qualities for each candidate considered to describe them as probable presidents of the US. These 
qualities are: confidence, readiness, visionary, honesty, logical, hopeful, unclear, persuasive, and inappropriate. Qualities that are selected to describe Clinton are: confidence (69.6\%), readiness $(37.5 \%)$ and visionary $(34.4 \%)$. On the other hand, qualities that are generally employed to characterize Trump are: inappropriate $(77.1 \%)$, confidence $(35.7 \%)$ and unclear $(35.4 \%)$. The least traits that show up to depict candidates are: "logical" (1.4\%) for Trump and "inappropriate" (7.1\%) for Clinton.

The statistical test investigates the significance of differences between groups in depicting each candidate with certain qualities and explores some traits that are significantly proved (0.05). "logical" and "persuasive" are more frequently used by the second group to describe Clinton, but "honesty" is identified by first group. However, "confidence", "persuasive", and "honesty" are obviously selected by first group to characterize Trump.

Table. 10 (P.24)

Table. $11(\mathrm{P} .24)$

7- Although it appears that Clinton is the favorite candidate for undoubtedly majority of Egyptians as leader with convincing visionary $(70.7 \%)$, no significance of differences is found between groups. Similar findings about their opinion of which candidate is considered more representing to the American universally known values. Clinton is more representative to these values $(78.6 \%)$ than Trump (21.4\%). Even though, no significance is emerged for differences between groups to support the impact of cultural variations in perceiving the US presidential candidates.

Table. 12 (P.25) 
Moreover, we don't have evidence that variance between groups in anticipating the next president of the US has correlation with any demographic variables. Exceptionally, the gender has been significantly proven to expect that Clinton will be the next president $(68.6 \%)$. It is obviously remarkable that almost half of males anticipate Trump to be the president, however only $21 \%$ of females sharing them the same expectation.

Table. 13 (P.25)

8- Many reasons have been suggested to justify the selection of certain candidate as a leader has full capacity to be the next president and to deliver convincing messages through his speeches to the public. These reasons include: the ability to propose creative solutions for the economic problems, demonstration of considerable respect to the basic values of the American society, communication in clear and simple language that influence a broader scale of the public. Speaking in an informative style concentrating on facts instead of controversial issues, looking believable and trustful and owning power enough to achieve the required change in the American citizens' lives in the right direction.

The most frequently reason has been selected to justify the convincing style of the candidate is his ability to communicate in a clear, simple, and direct language that can easily influence large scale of people $(50 \%)$. However, the last reason is speaking in an informative style $(21 \%)$. Despite of these clear findings, only "the ability to propose creative solutions for the economic problems" is the reason that showed significance as a choice for the first group.

Table. 14 (P.25)

9- Finally, the last finding is about the distracting aspects that Egyptians observe about both candidates and consider it was inconvenient for the next president of the US. These aspects include 
the unaccepted "style of clothing", "hair dressing", "facial expressions", "tone of voice", "hand movements", "body gestures" and general spirit. Clinton and Trump found equal in only one aspect which is "style of clothing", while Trump exceeds Clinton dramatically in all other aspects specially "tone of voice", "hair dressing" and "facial expressions" that considered distracting aspects during watching the candidates as speakers in the presidential debates. Three of the distracting aspects have significance while comparing differences between groups. The three aspects are: "the style of clothing", "the tone of voice", and "the body gestures".

Table. 15 (P.25)

\section{Discussion:}

The first group considered to be mainly Arabic education; the dominant culture is Arabic Egyptian that is influenced by original aspects of this identity basically the religion, traditions, customs, habits, history, experience, expectations, interests, ambitions, stereotyping, images, and style of living. This group tends to speak in Arabic with its Egyptian slang often in both real and virtual levels. They always more involved in practicing the original cultural customs and traditions. They apparently interested in the national history and feel proud of it. On the contrary, they didn't study the world history and they don't care about foreign affairs even if it has major effect on their daily life.

The people of this group generally prefer to stay in Egypt forever and rarely change this attitude. Therefore, they tend to exert every possible effort to establish good conditions for living inside Egypt regardless any better opportunities that may exist outside it. Consequently, they tend to follow the national affairs that help them to stay aware of their environment and maintain local relationships that can strengthen their position inside the society.

The second group is mainly foreign education in either English, French, or German languages. Members of this group tend to speak in English specially in the virtual level of their life within social media networks. They seem to be more interested in foreign affairs as they 
have some knowledge about world history. Moreover, they obviously connected to the Western culture in many ways. Majority of students of this group dream or plan to travel abroad for work or for postgraduate studies. They prefer to join one of the multinational companies if they decided to stay in Egypt. They evaluate establishing bridges with friends from different cultures or countries and consider it beneficial for their future. Consequently, it is supposed to show greater interest of the US presidential elections 2016 than the first Arabic culture group.

Based on Philipsen's Speech codes premises, the researcher assumes that there are significant differences can be revealed between the two groups in imaging both male and female candidates with some characteristics. This assumption has been partially proven in describing the candidates with "honesty" and "persuasion" and particularly in characterizing Clinton as "logical" speaker and Trump as "confident" speaker.

The Egyptian newspaper focused on Trump more than Clinton characterizing him with both negative and positive traits such as: "trustful", "determined" and has ability to create solutions for the society economic problems. The negative traits that included in content about Clinton is remarkable. Al- Ahram characterized Clinton as "corrupted" and "criminal" person regarding the catastrophic consequences of US foreign policy in the Middle East during her secretary of states. Even though, the newspaper described Clinton as "efficient" and "less harmful" leader but in smaller number of articles.

Although Trump repeatedly declaration that Muslims immigration should be panned for national security purposes, a considerable percentage of Egyptian conservatives believe he is the best president for the US and world. This observation suggests a question about the potential relationship between conservativeness and unexpected preferences to illogical decisions in certain national or international affairs. (Popkova, A. 2017)

\section{Conclusion:}

1- There is some evidence that different cultures at the same society are connected to adopting certain opinions about foreign affairs news and portraying characteristics of public figures that contribute in constructing visions and expectations. 
2- Although the frequency of publishing news and opinion articles in Al Ahram newspaper about Trump is bigger than Clinton, the negative characteristics that describe both candidates are equal and the dominant argument included in the opinion articles is that no one has preferential advantages to ensure his eligibility to becoming the next president of the US.

3- The news frames that are significantly used with candidates are: "Attacking" and "Differentiation" with Clinton, while "Expectation", "Accusation", "Promises", "Situation adjustment", "Percussive", "Conspiracy" and "Diplomacy" are the main news frames with Trump.

4- Despite the intensive focus of the official newspapers to analyze the US presidential elections and describing the characteristics of each candidate, it seems that it has very limited impact in formulating the public opinion views about foreign affairs. Facebook, YouTube, and TV satellite channels are playing the major role in this context.

5- Some characteristics related to candidates showed no significant relationship with different groups. As an illustrate, "narcissist" and "filthy rich" are the lowest frequencies described Trump. Even though, Trump's speeches were rated as more grandiose than those of his competitors (Ahmadian, S., Azarshahi, S. \& Paulhus, D. 2017) but it seems like this grandiosity diminished remarkably in the last stages of the presidency race specially during the three final debates with Clinton.

6- Although twitter is increasingly used as a media platform for interactive communication between candidate and supporters in US presidential elections, especially in Trump's case, which supposed to enrich news headlines (Conway, B., \& Kenski, K., \& Wang, D. 2013), twitter is almost outside the media sources used by Egyptians to follow the foreign affairs issues.

7- "Populism" is one of the important news frames should be included to any further analysis of the presidential speeches for either democratic or republican candidates. (Bonikowski, B., \& Gidron, N. 2016) as populism is mainly a fundamental tool of political opponents varies in accordance with candidate's relative positions in the political field. 


\section{References}

Aalberg, T., \&Jenssen, A.T. (2007). Gender stereotyping of political candidates. An experimental study of political communication. Nordicom Review. $28,1$. p17-32

Ahmadian, S., Azarshahi, S. \& Paulhus, D. (2017). Explaining Donald Trump via communication style: Grandiosity, informality, and dynamism. Personality and Individual Differences 107. 49-53

Benoit, w. (2013). Candidates Personal qualities in political leaders debates. Human Communication. Vol. 16, Issue 2, p.87

Ben-Ur, J. \& Newman, B. (2002). Motives, Perceptions and voting intention of voters in the 2000 US. Psychology\& Marketing, Vol. 19 (12), pp. 1047-1065

Bonikowski, B., \& Gidron, N. (2016). The populist style in American politics: presidential campaign discourse, 1952-1996. Social Forces 94. 4. 1593-1621

Bowden, G. (2010). Obama, Palin, and weber: Charisma and social change in the 2008 US election. Canadian Review of Sociology/Revue canadienne de sociologie 47(2): $171-190$

Brewer, P. et al. (2014). Public perceptions regarding the authenticity of the 2012 presidential candidates. Presidential studies Quarterly. Vol. 44, No. 4 Dec., pp. $742-757$

Conway, B., \& Kenski, K., \& Wang, D. (2013). Twitter use by presidential primary candidates during the 2012 campaign. American Behavioural Scientist. 57. 11. 1596-1610

Dow, B. 2017. Taking Trump seriously: Persona and presidential politics in 2016. Women's Studies in Communication. Vol 40. No. 2. p136-139

Glass, D. P. (2001). Evaluating presidential candidates: Who focuses on their personal attributes? Public Opinion Quarterly. Vol. 49, pp. 517- 534

Greogory JR, S., \& Gallagher, T. (2002). Spectral analysis of candidates' nonverbal vocal communication: predicting US presidential election outcomes. Social Psychology Quarterly. Vol. 65. No. 3. 298-308

Griffin, E. (2012). A First look at communication theory. McGraw. Hill

International Edition.

Guzman, F. \& Sierra, V. (2009). A political candidate's brand image scale: Are political candidates' brands, Brand Management, Vol. 17, 3, 207-217

Hacker, K. et al, (2000). Components of candidate images: Statistical analysis of the issue-persona dichotomy in the presidential campaign of 1996.

Communication Monographs, Vol. 67, No. 3, September, pp. 227-238

Hardy, B. W. \& Jamieson, K. (2005). Can a poll affect perception of candidate traits? Public Opinion Quarterly, Vol. 69, No. 5, Special Issue, pp 725-743

Hoegg, J \& Lewis, M.V. (2011). The impact of candidate Appearance and advertising strategies on election results. Journal of Marketing Research, Vol. xlviii, October, pp 895-909

Kim, Y. 2012. Politics of representation in the digital media environment. Presentation of the female candidate between news coverage and the web site in the 2007 Korean Presidential primary. Asian Journal of Communication. Vol. 22, No. 6, Dec. p601-620 
Oates, S., Moe, w. (2016). Donald Trump and the "Oxygen of publicity": branding, social media, and mass media in the 2016 presidential primary elections. American Political Science Association Annual Meeting. August 31.

Petre, D. et al (2010). The psychological profile of the candidates in the 2009 presidential elections. A classification of convinced supporters. Journal of Media Research. No.8. p25-45

Philipsen, G. (2001). Ethnography of speaking. Elsevier science \&Technology.

Philipsen, G. (2010). Some thoughts on how to approach finding one's feet in unfamiliar cultural terrain. Communication Monographs. Vol. 77, No. 2, June 2010, 160-168

Philipsen, G., Coutu, L. \& Covarrubias, P. (2005). Speech codes theory: restatement, revisions, and respond to criticism. Theorizing about intercultural communication. Thousand Oaks, Calif.: Sage.

Popkova, A. (2017). Putin is playing chess and I think we are playing marbles. Vladimir Putin's soft power and the American right. The International Communication Gazette. 0. 1-22

Porath, W., et al. (2014). Personalization, privatization, and campaign strategies in newspaper coverage of two Chilean presidential elections, 1989-2009. Communication \&Society 27(4), 95-112

Slatcher, R., Chung, K., Pennebaker, J. \& Stone, L. (2007). Winning words: individual differences in linguistic style among U.S. presidential and vice presidential candidates. Journal of Research in Personality 41. 63-75

Streitmatter, R. (1985). The impact of presidential personality on news coverage in major newspapers. Journalism\& Mass Communication Quarterly. Volume 62, issue 1 , pp. 66-73

Verhulst, B. et al (2010). The attractiveness halo: Why some candidates are perceived more favourably than others. J Nonverbal Behav. 34 pp. 111-117

Verser, R. \&Wicks, R. (2006). Managing voter impressions: The use of images on presidential candidate websites during the 2000 campaign. Journal of Communication. No. 56.p178-197

Warner, B. R. \& Banwart, M. C. (2016). A Multifactor Approach to Candidate Image. Communication Studies, Vol. 67, No. 3, July-August, pp. 259-279

Wattenberg, M. (2016). The declining relevance of candidate personal attributes in presidential elections. Presidential Studies Quarterly. Vol 46, No. 1, March, pp 125-139

Wattier, M. J. (2004). The Clinton Factor: The effects of Clinton's personal image in 2000 presidential primaries and in the general election. White House Studies, Vol. 4, No. 4, pp. 467-488 
Appendices:

Table 1

\begin{tabular}{|cl|c|c|c|c|}
\hline & & Frequency & $\%$ & $\begin{array}{c}\text { Valid } \\
\text { Percent }\end{array}$ & C.Percent \\
\hline Valid & April & 26 & 8.1 & 8.1 & 8.1 \\
& May & 17 & 5.3 & 5.3 & 13.4 \\
& June & 11 & 3.4 & 3.4 & 16.8 \\
July & 16 & 5.0 & 5.0 & 21.7 \\
Aug & 26 & 8.1 & 8.1 & 29.8 \\
Sept & 38 & 11.8 & 11.8 & 41.6 \\
Oct & 60 & 18.6 & 18.6 & 60.2 \\
Nov & 125 & 38.8 & 38.8 & 99.1 \\
Dec & 3 & .9 & .9 & 100.0 \\
Total & 322 & 100.0 & 100.0 & \\
\hline
\end{tabular}

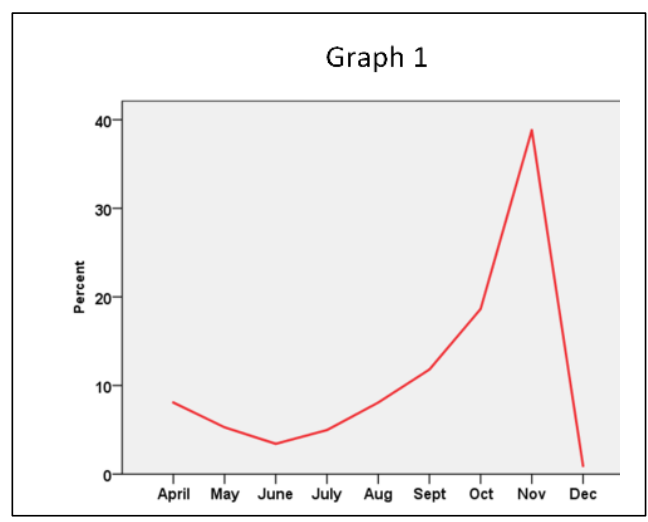

Table 2

\begin{tabular}{|l|c|c|c|c|}
\hline \multirow{2}{*}{ News Frames } & \multicolumn{3}{|c|}{ Presidential Candidates } & \multirow{2}{*}{ Total } \\
\cline { 2 - 4 } & Trump & Hillary & Both & \\
\hline Expectations & 29 & 22 & 8 & 59 \\
\hline Attacking & 15 & 25 & 14 & 54 \\
\hline Accusation & 5 & 3 & 30 & 38 \\
\hline Promises & 21 & 3 & 6 & 30 \\
\hline Diplomacy & 19 & 4 & 3 & 26 \\
\hline Determination & 11 & 9 & 3 & 23 \\
\hline Differentiation & 2 & 6 & 13 & 21 \\
\hline Sit_Adjustment & 12 & 3 & 2 & 17 \\
\hline Percussive & 12 & 2 & 2 & 16 \\
\hline Conspiracy & 10 & 1 & 4 & 15 \\
\hline Informative & 3 & 1 & 2 & 6 \\
\hline Patriotism & 1 & 2 & 3 & 6 \\
\hline
\end{tabular}


Table 3

\begin{tabular}{|c|c|c|c|c|}
\hline \multicolumn{5}{|c|}{ Hypothesis Test Summary } \\
\hline & Null Hypothesis & Test & Sig. & Decision \\
\hline 1 & $\begin{array}{l}\text { The distribution of } F \text {. Patriotism is } \\
\text { the same across categories of } \\
\text { Candidate. }\end{array}$ & $\begin{array}{l}\text { Independent- } \\
\text { Samples } \\
\text { Kruskal- } \\
\text { Wallis Test }\end{array}$ & .479 & $\begin{array}{l}\text { Retain the } \\
\text { null } \\
\text { hypothesis. }\end{array}$ \\
\hline 2 & $\begin{array}{l}\text { The distribution of } F \text {. Promises is } \\
\text { the same across categories of } \\
\text { Candidate. }\end{array}$ & $\begin{array}{l}\text { Independent- } \\
\text { Samples } \\
\text { Kruskal- } \\
\text { Wallis Test }\end{array}$ & .001 & $\begin{array}{l}\text { Reject the } \\
\text { null the } \\
\text { hypothesis. }\end{array}$ \\
\hline 3 & $\begin{array}{l}\text { The distribution of } F \text {. Determination } \\
\text { is the same across categories of } \\
\text { Candidate. }\end{array}$ & $\begin{array}{l}\text { Independent- } \\
\text { Samples } \\
\text { Kruskal- } \\
\text { Wallis Test }\end{array}$ & .144 & $\begin{array}{l}\text { Retain the } \\
\text { null } \\
\text { hypothesis. }\end{array}$ \\
\hline 4 & $\begin{array}{l}\text { The distribution of } F \text {. Differentiation } \\
\text { is the same across categories of } \\
\text { Candidate. }\end{array}$ & $\begin{array}{l}\text { Independent- } \\
\text { Samples } \\
\text { Kruskal- } \\
\text { Wallis Test }\end{array}$ & .003 & $\begin{array}{l}\text { Reject the } \\
\text { nufl the } \\
\text { hypothesis. }\end{array}$ \\
\hline 5 & $\begin{array}{l}\text { The distribution of F. Sit_Adjustment } \\
\text { is the same across categories of } \\
\text { Candidate. }\end{array}$ & $\begin{array}{l}\text { Independent- } \\
\text { Samples } \\
\text { Kruskal- } \\
\text { Wallis Test }\end{array}$ & .021 & $\begin{array}{l}\text { Reject the } \\
\text { null } \\
\text { hypothesis. }\end{array}$ \\
\hline 6 & $\begin{array}{l}\text { The distribution of F. Percussive is } \\
\text { the same across categories of } \\
\text { Candidate. }\end{array}$ & $\begin{array}{l}\text { Independent- } \\
\text { Samples } \\
\text { Kruskal- } \\
\text { Wallis Test }\end{array}$ & .010 & $\begin{array}{l}\text { Reject the } \\
\text { null thes } \\
\text { hypothesis. }\end{array}$ \\
\hline 7 & $\begin{array}{l}\text { The distribution of } F \text {. Accusation is } \\
\text { the same across categories of } \\
\text { Candidate. }\end{array}$ & $\begin{array}{l}\text { Independent- } \\
\text { Samples } \\
\text { Kruskal- } \\
\text { Wallis Test }\end{array}$ & .000 & $\begin{array}{l}\text { Reject the } \\
\text { null the } \\
\text { hypothesis. }\end{array}$ \\
\hline 8 & $\begin{array}{l}\text { The distribution of } F \text {. Attacking is } \\
\text { the same across categories of } \\
\text { Candidate. }\end{array}$ & $\begin{array}{l}\text { Independent- } \\
\text { Samples } \\
\text { Kruskal- } \\
\text { Wallis Test } \\
\end{array}$ & .014 & $\begin{array}{l}\text { Reject the } \\
\text { null the } \\
\text { hypothesis. }\end{array}$ \\
\hline 9 & $\begin{array}{l}\text { The distribution of } F \text {. Diplomacy is } \\
\text { the same across categories of } \\
\text { Candidate. }\end{array}$ & $\begin{array}{l}\text { Independent- } \\
\text { Samples } \\
\text { Kruskal- } \\
\text { Wallis Test }\end{array}$ & .001 & $\begin{array}{l}\text { Reject the } \\
\text { null } \\
\text { hypothesis. }\end{array}$ \\
\hline 10 & $\begin{array}{l}\text { The distribution of } F \text {. Conspiracy is } \\
\text { the same across categories of } \\
\text { Candidate. }\end{array}$ & $\begin{array}{l}\text { Independent- } \\
\text { Samples } \\
\text { Kruskal- } \\
\text { Wallis Test }\end{array}$ & .048 & $\begin{array}{l}\text { Reject the } \\
\text { null the } \\
\text { hypothesis. }\end{array}$ \\
\hline 11 & $\begin{array}{l}\text { The distribution of } F \text {. Informative is } \\
\text { the same across categories of } \\
\text { Candidate. }\end{array}$ & $\begin{array}{l}\text { Independent- } \\
\text { Samples } \\
\text { Kruskal- } \\
\text { Wallis Test }\end{array}$ & .757 & $\begin{array}{l}\text { Retain the } \\
\text { null the } \\
\text { hypothesis. }\end{array}$ \\
\hline 12 & $\begin{array}{l}\text { The distribution of } F \text {. Expectations is } \\
\text { the same across categories of } \\
\text { Candidate. }\end{array}$ & $\begin{array}{l}\text { Independent- } \\
\text { Samples } \\
\text { Kruskal- } \\
\text { Wallis Test }\end{array}$ & .005 & $\begin{array}{l}\text { Reject the } \\
\text { null the } \\
\text { hypothesis. }\end{array}$ \\
\hline
\end{tabular}

Asymptotic significances are displayed. The significance level is .05

Table 4

\begin{tabular}{|l|c|c|}
\hline & Mean & Std. Deviation \\
\hline Art_Thesis1 & .03 & .174 \\
Art_Thesis2 & .05 & .218 \\
Art_Thesis3 & .10 & .326 \\
Art_Thesis4 & .08 & .273 \\
Art_Thesis5 & .04 & .190 \\
Art_Thesis6 & .07 & .263 \\
Art_Thesis7 & .08 & .268 \\
\hline
\end{tabular}


Egyptian Media Coverage and Cultural Differences Impact In Perceiving the US Presidential Candidates 2016

\section{Table 5}

\begin{tabular}{|c|c|c|c|c|c|c|c|}
\hline & $\begin{array}{c}\text { Art_Thesi } \\
\text { s1 }\end{array}$ & $\begin{array}{c}\text { Art_Thesi } \\
\text { s2 }\end{array}$ & $\begin{array}{c}\text { Art_Thesi } \\
\text { s3 }\end{array}$ & $\begin{array}{c}\text { Art_Thesi } \\
\text { s4 }\end{array}$ & $\begin{array}{c}\text { Art_Thesi } \\
\text { s5 }\end{array}$ & $\begin{array}{c}\text { Art_Thesi } \\
\text { s6 }\end{array}$ & $\begin{array}{c}\text { Art_Thesi } \\
\text { s7 }\end{array}$ \\
\hline $\begin{array}{c}\text { Chi- } \\
\text { Squar } \\
\text { df }\end{array}$ & $283.242^{\mathrm{a}}$ & $261.180^{\mathrm{a}}$ & $485.149^{\mathrm{b}}$ & $226.398^{\mathrm{a}}$ & $275.789^{\mathrm{a}}$ & $232.178^{\mathrm{c}}$ & $228.788^{\mathrm{c}}$ \\
$\begin{array}{c}\text { Asym } \\
\text { p. Sig. }\end{array}$ & 1 & 1 & 1 & 1 & 1 & 1 & 1 \\
& .000 & .000 & .000 & .000 & .000 & .000 & .000 \\
\hline
\end{tabular}

Table 6

\begin{tabular}{|c|c|c|c|c|}
\hline \multicolumn{5}{|c|}{ Hypothesis Test Summary } \\
\hline & Null Hypothesis & Test & Sig. & Decision \\
\hline 1 & $\begin{array}{l}\text { The distribution of T.T.Racist is the } \\
\text { same across categories of } \\
\text { Candidate. }\end{array}$ & $\begin{array}{l}\text { Independent- } \\
\text { Samples } \\
\text { Kruskal- } \\
\text { Wallis Test }\end{array}$ & .000 & $\begin{array}{l}\text { Reject the } \\
\text { nulf } \\
\text { hypothesis. }\end{array}$ \\
\hline 2 & $\begin{array}{l}\text { The distribution of T.T-Cyclonic is } \\
\text { the same across categories of } \\
\text { Candidate. }\end{array}$ & $\begin{array}{l}\text { Independent- } \\
\text { Samples } \\
\text { Kruskal- } \\
\text { Wallis Test } \\
\end{array}$ & .000 & $\begin{array}{l}\text { Reject the } \\
\text { nulf } \\
\text { hypothesis. }\end{array}$ \\
\hline 3 & $\begin{array}{l}\text { The distribution of T.T-Insufficient is } \\
\text { the same across categories of } \\
\text { Candidate. }\end{array}$ & $\begin{array}{l}\text { Independent- } \\
\text { Samples } \\
\text { Kruskal- } \\
\text { Wallis Test } \\
\end{array}$ & .000 & $\begin{array}{l}\text { Reject the } \\
\text { nulf } \\
\text { hypothesis. }\end{array}$ \\
\hline 4 & $\begin{array}{l}\text { The distribution of T.T Determined } \\
\text { is the same across categories of } \\
\text { Candidate. }\end{array}$ & $\begin{array}{l}\text { Independent- } \\
\text { Sammeles } \\
\text { Kruskal- } \\
\text { Wallis Test }\end{array}$ & .000 & $\begin{array}{l}\text { Reject the } \\
\text { null thesis. } \\
\text { hypothes. }\end{array}$ \\
\hline 5 & $\begin{array}{l}\text { The distribution of T.T-Narcissist is } \\
\text { the same across categories of } \\
\text { Candidate. }\end{array}$ & $\begin{array}{l}\text { Independent- } \\
\text { Samples } \\
\text { Kruskal- } \\
\text { Wallis Test } \\
\end{array}$ & .083 & $\begin{array}{l}\text { Retain the } \\
\text { null } \\
\text { hypothesis. }\end{array}$ \\
\hline 6 & $\begin{array}{l}\text { The distribution of } \mathrm{T} \text {.T_Corrupted is } \\
\text { the same across categories of } \\
\text { Candidate. }\end{array}$ & $\begin{array}{l}\text { Independent- } \\
\text { Sameles } \\
\text { Kruskal- } \\
\text { Wallis Test } \\
\end{array}$ & .001 & $\begin{array}{l}\text { Reject the } \\
\text { null the } \\
\text { hypothesis. }\end{array}$ \\
\hline 7 & $\begin{array}{l}\text { The distribution of T.T_Trustful is } \\
\text { the same across categories of } \\
\text { Candidate. }\end{array}$ & $\begin{array}{l}\text { Independent- } \\
\text { Samples } \\
\text { Kruskal- } \\
\text { Wallis Test }\end{array}$ & .000 & $\begin{array}{l}\text { Reject the } \\
\text { null thesis. } \\
\text { hypothesis. }\end{array}$ \\
\hline 8 & $\begin{array}{l}\text { The distribution of T. T-Filthy Rich } \\
\text { is the same across categories of } \\
\text { Candidate. }\end{array}$ & $\begin{array}{l}\text { Independent- } \\
\text { Sammles } \\
\text { Kruskal- } \\
\text { Wallis Test }\end{array}$ & .370 & $\begin{array}{l}\text { Retain the } \\
\text { null th } \\
\text { hypothesis. }\end{array}$ \\
\hline 9 & $\begin{array}{l}\text { The distribution of T.T_Ignorant is } \\
\text { the same across categories of } \\
\text { Candidate. }\end{array}$ & $\begin{array}{l}\text { Independent- } \\
\text { Sammles } \\
\text { Kruskal- } \\
\text { Wallis Test } \\
\end{array}$ & .002 & $\begin{array}{l}\text { Reject the } \\
\text { null the } \\
\text { hypothesis. }\end{array}$ \\
\hline
\end{tabular}

Table 7

\begin{tabular}{|c|c|c|c|c|c|}
\hline \multirow{2}{*}{ trait } & \multicolumn{3}{|c|}{ Candidate } & \multirow{2}{*}{ total } & \multirow{2}{*}{ Chi } \\
\cline { 2 - 4 } & $\mathrm{T}$ & $\mathrm{C}$ & $\mathrm{B}$ & & \\
\hline Racist & 16 & 1 & 20 & 37 &, 000 \\
\hline Cyclonic & 31 & 9 & 44 & 84 &, 000 \\
\hline Insufficient & 34 & 18 & 52 & 104 &, 000 \\
\hline Determined & 57 & 10 & 30 & 97 &, 000 \\
\hline Narcissist & 3 & 0 & 5 & 8 &, 083 \\
\hline Corrupted & 33 & 25 & 63 & 121 & .001 \\
\hline Trustful & 35 & 6 & 14 & 55 &, 000 \\
\hline Filthy rich & 4 & 1 & 1 & 6 &, 368 \\
\hline Ignorant & 15 & 2 & 18 & 35 &, 002 \\
\hline Efficient & 17 & 54 & 50 & 121 &, 000 \\
\hline Liar & 9 & 14 & 16 & 39 &, 095 \\
\hline Devilish & 5 & 3 & 5 & 13 &, 809 \\
\hline Traitor & 19 & 13 & 25 & 57 &, 077 \\
\hline Criminal & 12 & 24 & 16 & 52 &, 009 \\
\hline Less harmful & 18 & 8 & 30 & 56 &, 000 \\
\hline
\end{tabular}


Table 8

\begin{tabular}{|c|c|c|c|c|}
\hline \multicolumn{5}{|c|}{ Hypothesis Test Summary } \\
\hline & Null Hypothesis & Test & Sig. & Decision \\
\hline 1 & $\begin{array}{l}\text { The distribution of C.T_Corrupted is } \\
\text { the same across categories of } \\
\text { Candidate. }\end{array}$ & $\begin{array}{l}\text { Independent- } \\
\text { Samples } \\
\text { Kruskal- } \\
\text { Wallis Test }\end{array}$ & .000 & $\begin{array}{l}\text { Reject the } \\
\text { null } \\
\text { hypothesis. }\end{array}$ \\
\hline 2 & $\begin{array}{l}\text { The distribution of C.T Efficient is } \\
\text { the same across categories of } \\
\text { Candidate. }\end{array}$ & $\begin{array}{l}\text { Independent- } \\
\text { Samples } \\
\text { Kruskal- } \\
\text { Wallis Test }\end{array}$ & .000 & $\begin{array}{l}\text { Reject the } \\
\text { null } \\
\text { hypothesis. }\end{array}$ \\
\hline 3 & $\begin{array}{l}\text { The distribution of C.T Liar is the } \\
\text { same across categories of } \\
\text { Candidate. }\end{array}$ & $\begin{array}{l}\text { Independent- } \\
\text { Samples } \\
\text { Kruskal- } \\
\text { Wallis Test }\end{array}$ & .096 & $\begin{array}{l}\text { Retain the } \\
\text { null } \\
\text { hypothesis. }\end{array}$ \\
\hline 4 & $\begin{array}{l}\text { The distribution of C.T Devilish is } \\
\text { the same across categories of } \\
\text { Candidate. }\end{array}$ & $\begin{array}{l}\text { Independent- } \\
\text { Samples } \\
\text { Kruskal- } \\
\text { Wallis Test }\end{array}$ & .809 & $\begin{array}{l}\text { Retain the } \\
\text { null } \\
\text { hypothesis. }\end{array}$ \\
\hline 5 & $\begin{array}{l}\text { The distribution of C.T Traitor is the } \\
\text { same across categories of } \\
\text { Candidate. }\end{array}$ & $\begin{array}{l}\text { Independent- } \\
\text { Samples } \\
\text { Kruskal- } \\
\text { Wallis Test }\end{array}$ & .078 & $\begin{array}{l}\text { Retain the } \\
\text { null } \\
\text { hypothesis. }\end{array}$ \\
\hline 6 & $\begin{array}{l}\text { The distribution of C.T_Criminal is } \\
\text { the same across categories of } \\
\text { Candidate. }\end{array}$ & $\begin{array}{l}\text { Independent- } \\
\text { Samples } \\
\text { Kruskal- } \\
\text { Wallis Test }\end{array}$ & .009 & $\begin{array}{l}\text { Reject the } \\
\text { null } \\
\text { hypothesis. }\end{array}$ \\
\hline 7 & $\begin{array}{l}\text { The distribution of } \mathrm{C} \text {. } \\
\mathrm{T} \text { Less Harmful is the same across } \\
\text { categories of Candidate. }\end{array}$ & $\begin{array}{l}\text { Independent- } \\
\text { Samples } \\
\text { Kruskal- } \\
\text { Wallis Test }\end{array}$ & .000 & $\begin{array}{l}\text { Reject the } \\
\text { null } \\
\text { hypothesis. }\end{array}$ \\
\hline
\end{tabular}

Asymptotic significances are displayed. The significance level is .05 .

Table 9

\begin{tabular}{|c|c|c|c|c|c|c|c|c|c|c|}
\hline & $\begin{array}{c}\text { Egy. } \\
\text { News- } \\
\text { papers }\end{array}$ & $\begin{array}{c}\text { Inter.News } \\
- \\
\text { papers }\end{array}$ & $\begin{array}{c}\text { Egy. } \\
\text { Channel } \\
\mathrm{s}\end{array}$ & $\begin{array}{c}\text { Egy. } \\
\text { Sites }\end{array}$ & $\begin{array}{c}\text { Inter. } \\
\text {.Site } \\
\mathrm{s}\end{array}$ & $\begin{array}{c}\text { You- } \\
\text { Tube }\end{array}$ & $\begin{array}{c}\text { Twitt } \\
\text { er }\end{array}$ & $\begin{array}{c}\text { Face } \\
- \\
\text { book }\end{array}$ & $\begin{array}{c}\text { Broa } \\
\mathrm{d}- \\
\text { cast }\end{array}$ & $\begin{array}{c}\text { Friend } \\
\mathrm{s}\end{array}$ \\
\hline $\begin{array}{c}\text { Chi- } \\
\text { Square } \\
\text { df }\end{array}$ & .956 & 8.877 & 4.573 & 6.146 & $\begin{array}{c}1.81 \\
9\end{array}$ & $\begin{array}{c}1.41 \\
6\end{array}$ & $\begin{array}{c}4.07 \\
4\end{array}$ & $\begin{array}{c}7.84 \\
2\end{array}$ & $\begin{array}{c}3.58 \\
0\end{array}$ & 2.842 \\
Asymp. & 1 & 1 & 1 & 1 & 1 & 1 & 1 & 1 & 1 & 1 \\
Sig. & .328 & .003 & .032 & .013 & .177 & .234 & .044 & .005 & .058 & .092 \\
\hline
\end{tabular}

a. Kruskal Wallis Test

b. Grouping Variable: Groups 
Table 10

Hypothesis Test Summary

\begin{tabular}{|c|c|c|c|c|}
\hline & Null Hypothesis & Test & Sig. & Decision \\
\hline 1 & $\begin{array}{l}\text { The distribution of T.T. Confidence is } \\
\text { the same across categories of } \\
\text { Groups. }\end{array}$ & $\begin{array}{l}\text { Independent- } \\
\text { Samples } \\
\text { Kruskal- } \\
\text { Wallis Test }\end{array}$ & .001 & $\begin{array}{l}\text { Reject the } \\
\text { null } \\
\text { hypothesis }\end{array}$ \\
\hline 2 & $\begin{array}{l}\text { The distribution of T.T.Readiness is } \\
\text { the same across categories of } \\
\text { Groups. }\end{array}$ & $\begin{array}{l}\text { Independent- } \\
\text { Samples } \\
\text { Kruskal- } \\
\text { Wallis Test }\end{array}$ & .113 & $\begin{array}{l}\text { Retain the } \\
\text { null } \\
\text { hypothesis. }\end{array}$ \\
\hline 3 & $\begin{array}{l}\text { The distribution of T.T.Vision is the } \\
\text { same across categories of Groups. }\end{array}$ & $\begin{array}{l}\text { Independent- } \\
\text { Samples } \\
\text { Kruskal- } \\
\text { Wallis Test }\end{array}$ & .683 & $\begin{array}{l}\text { Retain the } \\
\text { null } \\
\text { hypothesis. }\end{array}$ \\
\hline 4 & $\begin{array}{l}\text { The distribution of T.T. Honesty is } \\
\text { the same across categories of } \\
\text { Groups. }\end{array}$ & $\begin{array}{l}\text { Independent- } \\
\text { Samples } \\
\text { Kruskal- } \\
\text { Wallis Test }\end{array}$ & .031 & $\begin{array}{l}\text { Reject the } \\
\text { null } \\
\text { hypothesis. }\end{array}$ \\
\hline 5 & $\begin{array}{l}\text { The distribution of T.T.Logical is the } \\
\text { same across categories of Groups. }\end{array}$ & $\begin{array}{l}\text { Independent- } \\
\text { Samples } \\
\text { Kruskal- } \\
\text { Wallis Test }\end{array}$ & .611 & $\begin{array}{l}\text { Retain the } \\
\text { null } \\
\text { hypothesis. }\end{array}$ \\
\hline 6 & $\begin{array}{l}\text { The distribution of T.T.Respective is } \\
\text { the same across categories of } \\
\text { Groups. }\end{array}$ & $\begin{array}{l}\text { Independent- } \\
\text { Samples } \\
\text { Kruskal- } \\
\text { Wallis Test }\end{array}$ & .618 & $\begin{array}{l}\text { Retain the } \\
\text { null } \\
\text { hypothesis. }\end{array}$ \\
\hline 7 & $\begin{array}{l}\text { The distribution of T.T. Hope is the } \\
\text { same across categories of Groups. }\end{array}$ & $\begin{array}{l}\text { Independent- } \\
\text { Samples } \\
\text { Kruskal- } \\
\text { Wallis Test }\end{array}$ & .792 & $\begin{array}{l}\text { Retain the } \\
\text { null } \\
\text { hypothesis }\end{array}$ \\
\hline 8 & $\begin{array}{l}\text { The distribution of T.T.Unclear is the } \\
\text { same across categories of Groups. }\end{array}$ & $\begin{array}{l}\text { Independent- } \\
\text { Samples } \\
\text { Kruskal- } \\
\text { Wallis Test }\end{array}$ & .674 & $\begin{array}{l}\text { Retain the } \\
\text { null } \\
\text { hypothesis. }\end{array}$ \\
\hline 9 & $\begin{array}{l}\text { The distribution of T.T.Persuasive is } \\
\text { the same across categories of } \\
\text { Groups. }\end{array}$ & $\begin{array}{l}\text { Independent- } \\
\text { Samples } \\
\text { Kruskal- } \\
\text { Wallis Test }\end{array}$ & .034 & $\begin{array}{l}\text { Reject the } \\
\text { null } \\
\text { hypothesis }\end{array}$ \\
\hline 10 & $\begin{array}{l}\text { The distribution of T.T. Inappropriate } \\
\text { is the same across categories of } \\
\text { Groups. }\end{array}$ & $\begin{array}{l}\text { Independent- } \\
\text { Samples } \\
\text { Kruskal- } \\
\text { Wallis Test }\end{array}$ & .051 & $\begin{array}{l}\text { Retain the } \\
\text { null } \\
\text { hypothesis. }\end{array}$ \\
\hline
\end{tabular}

Asymptotic significances are displayed. The significance level is .05 . 
Table 11

Hypothesis Test Summary

\begin{tabular}{|c|c|c|c|c|}
\hline & Null Hypothesis & Test & Sig. & Decision \\
\hline 1 & $\begin{array}{l}\text { The distribution of C.T. Confedince is } \\
\text { the same across categories of } \\
\text { Groups. }\end{array}$ & $\begin{array}{l}\text { Independent- } \\
\text { Samples } \\
\text { Kruskal- } \\
\text { Wallis Test }\end{array}$ & .165 & $\begin{array}{l}\text { Retain the } \\
\text { null } \\
\text { hypothesis. }\end{array}$ \\
\hline 2 & $\begin{array}{l}\text { The distribution of C.T. Readiness is } \\
\text { the same across categories of } \\
\text { Groups. }\end{array}$ & $\begin{array}{l}\text { Independent- } \\
\text { Samples } \\
\text { Kruskal- } \\
\text { Wallis Test }\end{array}$ & .430 & $\begin{array}{l}\text { Retain the } \\
\text { null } \\
\text { hypothesis. }\end{array}$ \\
\hline 3 & $\begin{array}{l}\text { The distribution of C.T.Vision is the } \\
\text { same across categories of Groups. }\end{array}$ & $\begin{array}{l}\text { Independent- } \\
\text { Samples } \\
\text { Kruskal- } \\
\text { Wallis Test }\end{array}$ & .319 & $\begin{array}{l}\text { Retain the } \\
\text { null } \\
\text { hypothesis. }\end{array}$ \\
\hline 4 & $\begin{array}{l}\text { The distribution of C.T. Honesty is } \\
\text { the same across categories of } \\
\text { Groups. }\end{array}$ & $\begin{array}{l}\text { Independent- } \\
\text { Samples } \\
\text { Kruskal- } \\
\text { Wallis Test }\end{array}$ & .001 & $\begin{array}{l}\text { Reject the } \\
\text { null } \\
\text { hypothesis. }\end{array}$ \\
\hline 5 & $\begin{array}{l}\text { The distribution of C.T. Logical is the } \\
\text { same across categories of Groups. }\end{array}$ & $\begin{array}{l}\text { Independent- } \\
\text { Samples } \\
\text { Kruskal- } \\
\text { Wallis Test }\end{array}$ & .000 & $\begin{array}{l}\text { Reject the } \\
\text { null } \\
\text { hypothesis. }\end{array}$ \\
\hline 6 & $\begin{array}{l}\text { The distribution of C.T.Respective is } \\
\text { the same across categories of } \\
\text { Groups. }\end{array}$ & $\begin{array}{l}\text { Independent- } \\
\text { Samples } \\
\text { Kruskal- } \\
\text { Wallis Test }\end{array}$ & .089 & $\begin{array}{l}\text { Retain the } \\
\text { null } \\
\text { hypothesis. }\end{array}$ \\
\hline 7 & $\begin{array}{l}\text { The distribution of } C \text {. T. Hope is the } \\
\text { same across categories of Groups. }\end{array}$ & $\begin{array}{l}\text { Independent- } \\
\text { Samples } \\
\text { Kruskal- } \\
\text { Wallis Test }\end{array}$ & .295 & $\begin{array}{l}\text { Retain the } \\
\text { null } \\
\text { hypothesis. }\end{array}$ \\
\hline 8 & $\begin{array}{l}\text { The distribution of C.T. Unclear is } \\
\text { the same across categories of } \\
\text { Groups. }\end{array}$ & $\begin{array}{l}\text { Independent- } \\
\text { Samples } \\
\text { Kruskal- } \\
\text { Wallis Test }\end{array}$ & .669 & $\begin{array}{l}\text { Retain the } \\
\text { null } \\
\text { hypothesis. }\end{array}$ \\
\hline 9 & $\begin{array}{l}\text { The distribution of C.T.Persuasive is } \\
\text { the same across categories of } \\
\text { Groups. }\end{array}$ & $\begin{array}{l}\text { Independent- } \\
\text { Samples } \\
\text { Kruskal- } \\
\text { Wallis Test }\end{array}$ & .034 & $\begin{array}{l}\text { Reject the } \\
\text { null } \\
\text { hypothesis. }\end{array}$ \\
\hline 10 & $\begin{array}{l}\text { The distribution of C.T.Inappropriate } \\
\text { is the same across categories of } \\
\text { Groups. }\end{array}$ & $\begin{array}{l}\text { Independent- } \\
\text { Samples } \\
\text { Kruskal- } \\
\text { Wallis Test }\end{array}$ & .058 & $\begin{array}{l}\text { Retain the } \\
\text { null } \\
\text { hypothesis. }\end{array}$ \\
\hline
\end{tabular}

Asymptotic significances are displayed. The significance level is 05 .

Table 12

More Convincing Candidate

\begin{tabular}{|c|c|c|c|}
\hline & $\begin{array}{c}\text { Frequ- } \\
\text { ency }\end{array}$ & $\begin{array}{c}\text { Valid } \\
\text { Percent }\end{array}$ & Cumulativ-e Percent \\
\hline 0 & 14 & 5.0 & 5.0 \\
Trump & 68 & 24.3 & 29.3 \\
Clinton & 198 & 70.7 & 100.0 \\
Total & 280 & 100.0 & \\
\hline
\end{tabular}


Table 13

\begin{tabular}{|c|c|c|c|c|c|c|c|c|}
\hline & Solutions & Evaluation & Communic-ation & Efficiency & Reliability & Informative & $\begin{array}{c}\text { American } \\
\text { Spirit }\end{array}$ & $\begin{array}{c}\text { Strong } \\
\text { Enough }\end{array}$ \\
\hline Chi-Square & 4.656 & 1.205 & 1.891 & .666 & .014 & .607 & .267 & 2.371 \\
Asymp. Sig. & .031 & .272 & .169 & .414 & .906 & .436 & .606 & .124 \\
\hline
\end{tabular}

b. Grouping Variable: Groups

Table 14

More Representative Candidate

\begin{tabular}{|c|c|c|c|}
\hline & Frequ-ency & Valid Percent & $\begin{array}{c}\text { Cumulativ- } \\
\text { e Percent }\end{array}$ \\
\hline Trump & 60 & 21.4 & 21.4 \\
Clinton & 220 & 78.6 & 100.0 \\
Total & 280 & 100.0 & \\
\hline
\end{tabular}

Table 15

\begin{tabular}{|c|c|c|c|c|c|c|c|}
\hline & Clothes & Hair Style & Voice & .F.expressions & Hand Move & Body Gestures & Spirit \\
\hline $\begin{array}{c}\text { Chi-Square } \\
\text { Asymp. } \\
\text { Sig. }\end{array}$ & 11.310 & .173 & 6.870 & 1.551 & 2.060 & 6.844 & .045 \\
& .001 & .678 & .009 & .213 & .151 & .009 & .831 \\
\hline
\end{tabular}

a. Kruskal Wallis Test

b. Grouping Variable: Groups 